\title{
Multiple Cellulase System from Streptomyces antibioticus ${ }^{1}$
}

\author{
M. D. ENGER ${ }^{2}$ AND B. P. SLEEPER \\ Department of Bacteriology, North Dakota State University, Fargo, North Dakota
}

Received for publication 18 July 1964

\begin{abstract}
Enger, M. D. (North Dakota State University, Fargo), ANd B. P. Slemper. Multiple cellulase system from Streptomyces antibioticus. J. Bacteriol. 89:23-27. 1965. - Starch-block zone electrophoresis was used to isolate five electrophoretically distinct, active cellulolytic components (I to V) from the crude extracellular cellulase system of Streptomyces antibioticus (strain C2A). Agar diffusion precipitin analyses demonstrated the immunological identity of components I, II, and III, and the nonidentity of IV and V with each other and with I to III. Kinetic studies of the purified enzymes showed a sharp decrease in the viscosity of the substrate, carboxymethylcellulose, with only a small increase in reducing sugars. These results indicated that all five enzymes are endocellulases.
\end{abstract}

Recent reports on microorganisms hydrolyzing cellulose indicate that multiple enzyme systems are frequently involved. For example, Trichoderma viride (Gilligan and Reese, 1954), Cellvibrio gilvus (Storvick and King, 1960), an unidentified streptomycete (Mandels, Miller, and Slater, 1961), and Polyporus versicolor (Pettersson and Porath, 1963) apparently elaborate multiple systems. Myrothecium verrucaria is believed by some to secrete several cellulases. However, Whitaker, Hanson, and Datta (1963) presented convincing evidence in favor of a single enzyme from this organism. Whitaker (1963) reviewed the problems in the isolation and characterization of cellulases.

Studies on the mechanism of action of the cellulases from $T$. viride (Gilligan and Reese, 1954) and $M$. verrucaria (Whitaker, 1954; Hanstein and Whitaker, 1963) indicate that these enzymes preferentially attack interior linkages if given substrates with a high degree of polymerization. However, with cellotriose as substrate, purified $M$. verrucaria cellulase shows a strong preference for the linkage adjacent to the nonreducing end of the molecule (Whitaker and Merler, 1956). C. gilvus is believed to carry out an endwise attack (Storvick and King, 1960).

${ }^{1}$ This paper is published with the approval of the Director, North Dakota Agricultural Experiment Station as Journal Article No. 51.

2 Present address: Biomedical Research Group, Los Alamos Scientific Laboratories, Los Alamos, N.M.

\section{Materials and Methods}

Strain C2A of Streptomyces antibioticus was isolated from soil on mineral-cellobiose medium and has been maintained in the lyophilized state. (We are indebted to T. G. Pridham, who advised on the identification of this organism.) For production of cellulase, the organism was grown on the following medium: $\mathrm{KH}_{2} \mathrm{PO}_{4}, 2 \mathrm{~g} ; \mathrm{NaCl}, 3 \mathrm{~g}$; $\mathrm{KNO}_{3}, 3 \mathrm{~g} ; \mathrm{MgSO}_{4} \cdot 7 \mathrm{H}_{2} \mathrm{O}, 0.5 \mathrm{~g} ; \mathrm{CaCl}_{2} \cdot 2 \mathrm{H}_{2} \mathrm{O}$, $0.4 \mathrm{~g} ; \mathrm{FeSO}_{4}, 20 \mathrm{mg} ; \mathrm{MnSO}_{4} \cdot \mathrm{H}_{2} \mathrm{O}, 10 \mathrm{mg}$; water, $1,000 \mathrm{ml}$; and cellulose paste prepared as described by Hungate (1950), $20 \mathrm{~g} ; \boldsymbol{p H}$ 7.2. Erlenmeyer flasks ( 1 liter) containing $350 \mathrm{ml}$ of the above medium were inoculated with $10 \mathrm{ml}$ of cellulosegrown culture and incubated on a rotary shaker at $30 \mathrm{C}$. When the medium showed appreciable cellulase activity (2 to 7 days), the cells were removed by centrifugation. Cellulase was precipitated from the cooled ( 0 to $5 \mathrm{C}$ ) supernatant fluid by the addition of 2 parts of cold acetone ( $-17 \mathrm{C})$. The precipitated material was recovered by centrifugation, taken up in water, and dialyzed against several changes of demineralized water for a total of $24 \mathrm{hr}$. The dialysis bags were also changed frequently, because cellophane tubing is attacked and weakened by cellulase. The aqueous enzyme preparation was then lyophilized and stored at $-17 \mathrm{C}$ as crude cellulase.

Preliminary experiments with crude enzyme preparations showed that the insoluble cellulose used as growth substrate can be degraded to the extent of about $20 \%$. However, for convenience, all subsequent experiments were performed with carboxymethylcellulose (CMC) (7LP-CMC; Hercules Powder Co., Wilmington, Del.) and no attempt was made to distinguish between cellulase and carboxymethylcellulase activity. Enzyme assays were based on the measurement of reducing 


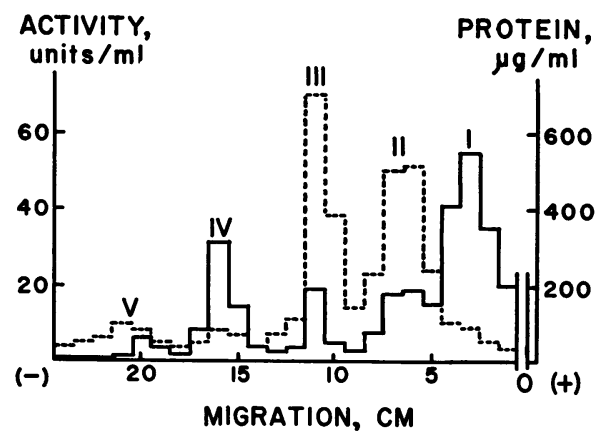

FIG. 1. Starch-block zone electrophoresis of crude Streptomyces antibioticus cellulase. Crude, lyophilized enzyme ( $\$ 0 \mathrm{mg}$ ) was added at origin (0). Current was applied for $20 \mathrm{hr}$ under the conditions described in the text. Electrophoretic fractions designated $I$ to $V$. Broken line $=$ protein, solid line = enzymatic activity.

sugar (Folin and Malmros, 1929) released after incubation of an appropriate volume of enzyme with $1.5 \mathrm{ml}$ of $1 \% \mathrm{CMC}$ and $0.5 \mathrm{ml}$ of $0.1 \mathrm{M}$ acetate buffer ( $p \mathrm{H} \mathrm{5.5)}$ in a Folin-Wu blood sugar tube at $38 \mathrm{C}$. The final volume was $2.5 \mathrm{ml}$. The reaction was stopped by addition of $0.4 \mathrm{ml}$ of the FolinMalmros cyanide-carbonate reagent. After addition of the other reagents for this method, the mixture was made up to $25 \mathrm{ml}$ and read in the Klett-Summerson colorimeter with filter $* 54$. Klett readings were converted to micrograms of cellobiose by comparison with a standard curve constructed with cellobiose. One unit of cellulase activity was defined as the amount of enzyme that released $100 \mu \mathrm{g}$ of cellobiose equivalents from the standard reaction mixture in $15 \mathrm{~min}$ at $38 \mathrm{C}$.

Starch-block zone electrophoresis of cellulase mixtures was carried out by the method of Paigan

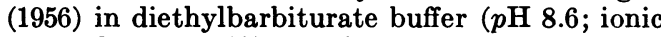
strength, 0.025). Electrophoresis was done at 0 to $5 \mathrm{C}$ for 15 to $20 \mathrm{hr}$ at a field strength of 7 to 10 $\mathrm{v} / \mathrm{cm}$ and a current of 10 to $25 \mathrm{ma}$. Sections (1 cm) of the starch block were eluted with cold acetate buffer ( $p$ H 5.5) and assayed for protein and enzyme activity. Protein was determined by the Folin-Ciocalteau method as described by Layne (1957) with casein as the standard.

Antisera against the crude cellulase were prepared by subcutaneous injection of young New Zealand white rabbits with lyophilized enzyme taken up in saline; $7 \mathrm{mg}$ were given three times a week for 3 weeks and $12.5 \mathrm{mg}$ after a 2-month rest. Agar diffusion precipitin analyses were performed by the method of Ouchterlony (1949) and a microtechnique similar to that of Yakulis and Heller (1959). A discussion of the interpretation of these methods was given by Crowle (1960).

For kinetic studies, $1.0 \mathrm{ml}$ of cellulase solution was added to duplicate $11.5-\mathrm{ml}$ samples of $1.6 \%$

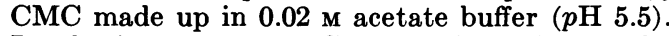
Incubation was at $38 \mathrm{C}$ for various times. The enzyme activity was stopped by the addition of $2.0 \mathrm{ml}$ of the Folin-Malmros cyanide-carbonate reagent. A $2.9-\mathrm{ml}$ sample was then taken for reducing sugar determination, and the viscosity of the remainder was determined with an Ostwald viscosimeter at $25 \mathrm{C}$. The results are expressed as specific viscosity, $\eta_{\mathrm{sp}}$.

\section{Results}

Starch-block electrophoresis. Preliminary runs indicated that all fractions of crude enzyme possessing carboxymethylcellulase activity moved toward the cathode during starch-block zone electrophoresis. Subsequent experiments were, therefore, performed with the origin positioned $4 \mathrm{~cm}$ from the anode end of the block. Electrophoresis experiments were highly reproducible, with protein and enzyme recoveries up to $88 \%$ and 70 to $85 \%$, respectively. The results of a typical run are shown in Fig. 1. The occurrence of five electrophoretically distinct fractions with cellulase activity on CMC is clearly demonstrated (designated I through V). To eliminate contamination from adjacent fractions, enzymes I through IV were rerun under the same conditions (Fig. 2). Reruns were made on partially resolved enzymes (Fig. 1) without storage or concentration, because these steps resulted in great loss of activity. Fraction V could not be rerun because of the small amounts available.

Agar diffusion precipitin analysis. Crude S. antibioticus cellulase preparations gave 7 or 8 precipitin lines when tested according to the method of Ouchterlony (1949). After the second electrophoresis (Fig. 2), the fractions were again tested (Fig. 3). These experiments demonstrated that, except for fraction $\mathrm{V}$, the isolated enzymes contained but one immunologically active component. Fraction $\mathrm{V}$ contained some contaminating protein. They also showed that cellulase fractions I, II, and III are immunologi-

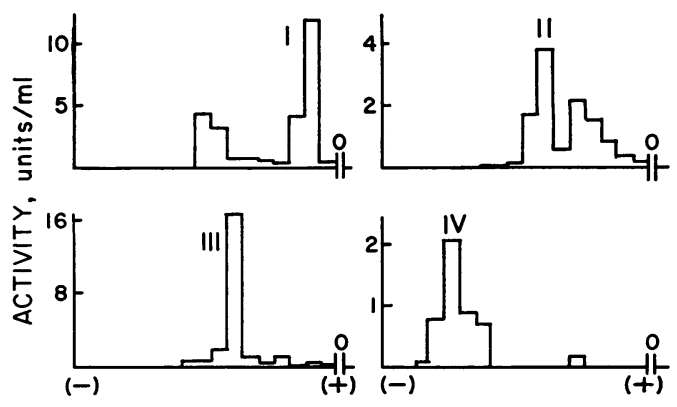

Fig. 2. Second electrophoresis of Streptomyces antibioticus cellulases I to IV. Conditions were the same as for Fig. 1 except that current was applied for $15.5 \mathrm{hr}$. Origin at 0 . 
cally related (their precipitin lines coalesce), whereas fractions IV and $V$ are not related immunologically to each other or to fractions I to III (the precipitin lines cross).

Kinetic studies. Preliminary chromatographic experiments with crude enzyme showed that the products of CMC hydrolysis included glucose, cellobiose, and other higher oligosaccharides. Experiments were then performed in which decrease in viscosity and increase in reducing sugars in the CMC solution were followed with time, as described in Materials and Methods. The crude cellulase mixture and all five separated enzyme fractions gave results (Fig. 4) essentially the same as those shown for fraction I. There was a rapid drop in viscosity after a relatively small increase in reducing sugars. On the basis of data similar to those shown, the crude and purified enzymes were compared for reduction of specific viscosity at the same level of CMC hydrolysis. Starting with $1 \mu$ mole of CMC (based on a molecular weight of CMC of 40,000), the per cent decrease in specific viscosity was calculated at the point where reducing sugar equivalent to $0.1 \mu$ mole of cellobiose had been released. The results were: for crude enzyme, $20 \%$ decrease; fraction I, $17 \%$; II, $22 \%$; III, $19 \%$; IV, $15 \%$; and $\mathrm{V}, 17 \%$. These data indicate that the cellulases attack primarily the internal, rather than the terminal, linkages of CMC; i.e., they are endocellulases.

Data for the five cellulases (Fig. 4) were also treated after the manner of Storvick and King (1960), who showed that for endocellulases a plot of $\log \Delta \mathrm{RS}$ (reducing sugars) against $\Delta[\eta]$ is linear, while exocellulases give a linear plot with $\log \Delta \mathrm{RS}$ against $\log \Delta[\eta]$. Figure 5 shows a plot of $\log \Delta \mathrm{RS}$ against $\Delta \eta_{\mathrm{sp}}$ for $S$. antibioticus cellulases. $\left(\eta_{\mathrm{sp}}\right.$ is assumed to be proportional to $[\eta]=$ intrinsic viscosity $=$ the limit of $\eta_{\mathrm{sp}} / \mathrm{C}$ as

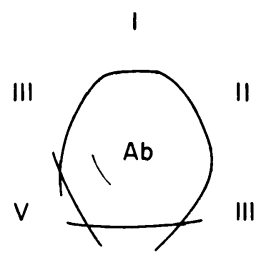

IV

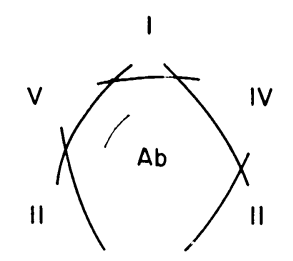

FIG. 3. Immunological relationships between the cellulases of Streptomyces antibioticus as shown by agar diffusion precipitin tests. The diagrams represent a summary of a number of experiments in which the various fractions were run in adjacent wells in all possible combinations. Ab, antibody well. I to $V$, wells containing electrophoretically purified cellulase fractions from Fig. 1 and 2.

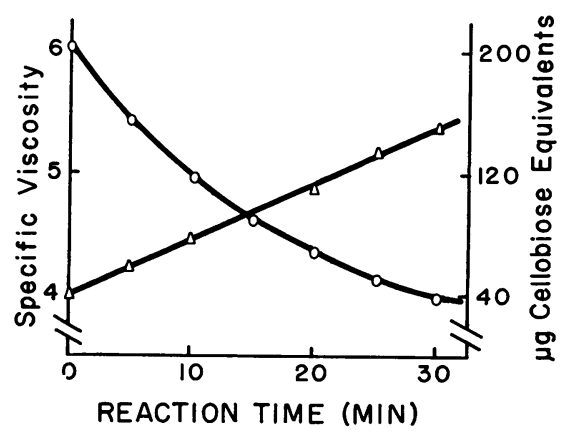

FIG. 4. Release of reducing sugars and decrease in specific viscosity as the result of the action of electrophoretically purified cellulase fraction $I$ on a CMC solution. Reducing sugars as cellobiose, $\triangle$; specific viscosity in centipoise, $\bigcirc$.

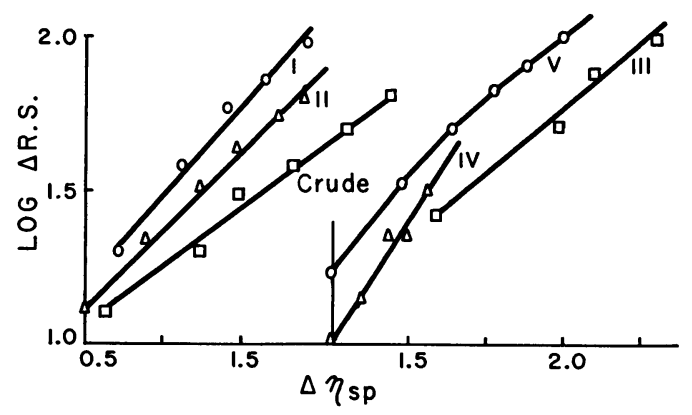

Fig. 5. Relationship between change in reducing sugars (R.S.) and change in viscosity ( $\eta_{\mathrm{sp}}$ ) brought about by the action of crude cellulase and fractions $I$ to $V$ on $C M C$.

$\mathrm{C}$ approaches zero, where $\mathrm{C}$ is the solute concentration in grams per $100 \mathrm{ml}$ of solution.)

Other properties. The crude cellulase preparations are stable for long periods in the lyophilized state, and were found to be stable for longer than 1 week at $10 \mathrm{C}$ when taken up in buffer. However, after separation of the fractions by electrophoresis, further manipulation had to be kept to a minimum. Freezing and thawing were particularly harmful. All five of the purified cellulases gave broad $p \mathrm{H}$ activity curves with optima at $p \mathbf{H}$ 6.5. There was only slightly less activity at $p \mathrm{H} 5.5$, which was used for all the experiments reported here.

\section{Discussion}

Two criteria of homogeneity have been met with cellulases I to IV from S. antibioticus. They were subjected to electrophoresis twice during the course of preparation (Fig. 1 and 2), and were shown to contain only one antigenic component when tested against antiserum to the 
crude enzyme mixture (Fig. 3). Although application of other tests for homogeneity must await accumulation of larger amounts of enzyme(s), fractions I to IV were separated sufficiently so that valid comparisons of their immunological relationships and their mode of action could be made. The results for fraction $\mathrm{V}$ are included, although there was still evidence for heterogeneity (Fig. 3). Cellulose-grown S. antibioticus contains an intracellular $\beta$-glucosidase (unpublished data), but no evidence could be obtained for $\beta$-glucosidase activity in any of the cellulase fractions described here.

Demonstration of the immunological "identity" of cellulases I to III by the coalescence of their precipitin lines (Fig. 3) shows that these enzymes contain a similar antigenic moiety in spite of differing electrophoretic mobilities. On the other hand, the immunological "nonidentity" of cellulases IV and V indicates possession of an antigenic moiety not common to each other or to fractions I to III. No information is available as to whether the five enzymes have a common enzymatically active site; it seems likely that they do. Neither is it known whether the antigenically determinant groups and the enzymatically active sites are the same. If the former is true, then the latter cannot be, at least in the case of fractions IV and V.

Several explanations have been proposed (Wroblewski, 1961) to account for the occurrence in the same organism of two or more enzymes with the same enzymatic activity (isozymes). In the case of the $S$. antibioticus cellulases, artifacts of preparation could well enter in, although no firm evidence has yet been obtained for interconversion of the fractions due to handling.

The electrophoretic heterogeneity and the immunological homogeneity of cellulase fractions I to III could be reasonably explained on the basis of the polymerization of a repeating protein subunit, as in the case of the beef lactate dehydrogenase (Markert, 1963). Polymerization of subunits might give different electrophoretic mobilities without necessarily altering the immunochemical specificity or the enzymatic activity. However, this would not explain the data for fractions IV and V, unless immunochemical specificity is maintained only up to a certain point and further polymerization or depolymerization of subunits alters the immunochemical specificity as well as the electrophoretic mobility.

The preliminary kinetic experiments reported here indicate a similarity in the mode of action of all of the S. antibioticus cellulases. They are endocellulases with similar properties when tested with CMC as substrate. Thus, the kinetic studies throw no light on the basis for the heterogeneity of this cellulase system. A comparison of the enzymes on substrates of widely different degrees of polymerization may provide more useful information.

Since only one property, electrophoretic mobility, allows distinction between the five cellulases, other differentiating properties are needed to explain the basis for the heterogeneity observed. Efforts to further characterize the five cellulase fractions are under way.

\section{ACKNowledgments}

We are indebted to Carol Braaten for valuable assistance in the production of the crude celullases.

This investigation was supported in part by Public Health Service research grant AI-00737 from the National Institute of Allergy and Infectious Diseases.

\section{Literature Cited}

Crowle, A. J. 1960. Interpretation of immunodiffusion tests. Ann. Rev. Microbiol. 14:161176.

Folin, O., and H. Malmros. 1929. An improved form of Folin's micro-method for blood sugar determinations. J. Biol. Chem. 83:115-120.

Gilligan, W., and E. T. Reese. 1954. Evidence for multiple components in microbial cellulases. Can. J. Microbiol. 1:90-107.

Hanstein, E. G., and D. R. Whitaker. 1963. Improved procedures for preparation and characterization of Myrothecium cellulase. IV. Characterization of activity toward $\beta$-methyl glucosides of $1 \rightarrow 4-\beta-D$-oligoglucosides. Can. J. Biochem. Physiol. 41:707-718.

Hungate, R. E. 1950. The anaerobic mesophilic cellulolytic bacteria. Bacteriol. Rev. 14:1-49.

LAYNe, E. 1957. Spectrophotometric and turbidimetric methods for measuring proteins, p. 448-450. In S. P. Colowick and N. O. Kaplan [ed.], Methods in enzymology, vol. 3. Academic Press, Inc., New York.

Mandels, M., G. L. Miller, and R. W. Slater, JR. 1961. Separation of fungal carbohydrases by starch-block zone electrophoresis. Arch. Biochem. Biophys. 93:115-121.

MARKERT, C. L. 1963. Lactate dehydrogenase isozymes: dissociation and recombination of subunits. Science 140:1329-1330.

Ouchterlony, O. 1949. Antigen-antibody reactions in gels. Acta Pathol. Microbiol. Scand. 26:507-515.

Paigan, K. 1956. Convenient starch electrophoresis apparatus. Anal. Chem. 28:284-286.

Pettersson, G., and J. Porath. 1963. Studies on cellulolytic enzymes. II. Multiplicity of the cellulolytic enzymes of Polyporus versicolor. Biochim. Biophys. Acta 67:9-15.

Storvick, W. O., and K. W. King. 1960. The complexity and mode of action of the cellulase system of Cellvibrio gilvus. J. Biol. Chem. 235: 303-307. 
WhitaKeR, D. R. 1954. Hydrolysis of a series of $\beta$-1,4-oligoglucosides by Myrothecium verrucaria cellulase. Arch. Biochem. Biophys. 63: 439-449.

WHITAKER, D. R. 1963. Criteria for characterizing cellulases, p. 51-70. In E. T. Reese [ed.], Advances in enzymic hydrolysis of cellulose and related materials. Pergamon Press, New York. Whitaker, D. R., K. R. Hanson, and P. R. DATTA. 1963. Improved procedures for preparation and characterization of Myrothecium cellulase. II. Purification procedures. Can. J. Biochem. Physiol. 41:671-696.

Whitaker, D. R., And E. Merler. 1956. Cleavage of cellotriose by Myrothecium cellulase. Can. J. Biochem. Physiol. 34:83-89.

Wroblewski, F. [ED.] 1961. Multiple molecular forms of enzymes. Ann. N.Y. Acad. Sci. 94:6551030.

YakUlis, V. J., ANd P. Heller. 1959. Rapid slide technic for double diffusion agar precipitin test. Amer. J. Clin. Pathol. 31:323-325. 